\title{
Adenoma detection rates decline with increasing procedural hours in an endoscopist's workload
}

\author{
Majid A Almadi MBBS, FRCPC, MSc ${ }^{1,2}$, Maida Sewitch PhD ${ }^{3}$, Alan N Barkun MD CM FRCPC MSc ${ }^{1,3}$, \\ Myriam Martel BSc ${ }^{1}$, Lawrence Joseph $\mathrm{PhD}^{3}$
}

\begin{abstract}
MA Almadi, M Sewitch, AN Barkun, M Martel, L Joseph. Adenoma detection rates decline with increasing procedural hours in an endoscopist's workload. Can J Gastroenterol Hepatol 2015;29(6):304-308.
\end{abstract}

BACKGROUND: Operator fatigue may negatively influence adenoma detection (AD) during screening colonoscopy.

OBJECTIVE: To better characterize factors affecting AD, including the number of hours worked, and the number and type of procedures performed before an index screening colonoscopy.

METHODS: A retrospective cohort study was conducted involving individuals undergoing a screening colonoscopy at a major tertiary care hospital in Montreal, Quebec. Individuals were identified using an endoscopic reporting database; $\mathrm{AD}$ was identified by an electronic chart review. A hierarchical logistic regression analysis was performed to determine the association between patient- and endoscopist-related variables and $A D$.

RESULTS: A total of 430 consecutive colonoscopies performed by 10 gastroenterologists and two surgeons were included. Patient mean $( \pm \mathrm{SD}$ ) age was $63.4 \pm 10.9$ years, $56.3 \%$ were males, $27.7 \%$ had undergone a previous colonoscopy and the cecal intubation rate was $95.7 \%$. The overall AD rate was $25.7 \%$. Age was associated with AD (OR 1.06 [95\% CI 1.03 to 1.08]), while female sex (OR 0.44 [95\% CI 0.25 to 0.75$]$ ), an indication for average-risk screening (OR 0.47 [95\% CI 0.27 to 0.80 ]) and an increase in the number of hours during which endoscopies were performed before the index colonoscopy (OR 0.87 [95\% CI 0.76 to 0.99]) were associated with lower AD rates. On exploratory univariable analysis, a threshold of $3 \mathrm{~h}$ of endoscopy time performed before the index colonoscopy was associated with decreased AD.

CONCLUSION: The number of hours devoted to endoscopies before the index colonoscopy was inversely associated with $\mathrm{AD}$ rate, with decreased performance possibly as early as within $3 \mathrm{~h}$. This metric should be confirmed in future studies and considered when optimizing scheduling practices.

Key Words: Adenoma detection; Endoscopy workload; Screening colonoscopy

\author{
Le taux de détection des adénomes inversement \\ proportionnel aux heures d'interventions par \\ l'endoscopiste
}

HISTORIQUE : La fatigue de l'opérateur peut nuire à la détection des adénomes (DA) pendant les coloscopies de dépistage.

OBJECTIF : Mieux caractériser les facteurs influant sur la DA, y compris le nombre d'heures de travail ainsi que le nombre et le type d'interventions effectuées avant une coloscopie de dépistage de référence. MÉTHODOLOGIE : Les chercheurs ont réalisé une étude rétrospective de cohorte auprès de personnes qui subissaient une coloscopie de dépistage dans un grand hôpital de soins tertiaires de Montréal, au Québec. Ils ont trouvé ces personnes dans une base de données des endoscopies. Ils ont examiné les dossiers électroniques pour en extraire les DA, puis ont effectué une analyse de régression logistique hiérarchique afin de déterminer l'association entre les variables liées aux patients et aux endoscopiques et les DA.

RÉSULTATS : Au total, 430 coloscopies consécutives effectuées par dix gastroentérologues et deux chirurgiens ont été incluses dans l'étude. Les patients avaient un âge moyen ( \pm ÉT) de 63,4 $\pm 10,9$ ans, 56,3\% étaient de sexe masculin, 27,7\% avaient déjà subi une coloscopie et $95,7 \%$ avaient subi une intubation cæcale. Le taux global de DA s'élevait à 25,7 \%. L'âge s'associait aux DA (RR 1,06 [95 \% IC 1,03 à $1,08]$ ), tandis que le sexe féminin (RR 0,44 [95 \% IC 0,25 à 0,75]), une indication de dépistage constituant un risque moyen (RR 0,47 [95\% IC $0,27$ à 0,80$]$ ) et une augmentation du nombre d'heures d'interventions endoscopiques avant la coloscopie de référence (RR 0,87 [95\% IC $0,76$ à 0,99$]$ ) s'associaient à une baisse du taux de DA. À l'analyse univariable exploratoire, un seuil de trois heures d'interventions endoscopiques avant la coloscopie de référence s'associait à une diminution des DA.

CONCLUSION : Le nombre d'heures consacrées aux endoscopies avant la coloscopie de référence était inversement proportionnel au taux de DA, le rendement pouvant diminuer moins de trois heures après le début des interventions endoscopiques. Il faudrait confirmer cette mesure lors de futures études et en tenir compte pour optimiser les horaires de travail.

CRC screening programs require allocation of significant resources (7), and improving the performance of colonoscopy as a screening tool has been the focus of many regulatory bodies and gastroenterology societies. There have been concerns about the rates of detection and removal of polyps in colonoscopies performed in Quebec, where they were found to be below sex-specific benchmarks (8). Furthermore, it was noted that the completion rates of colonoscopies as well as the reporting of key quality metrics were suboptimal, at best, in Manitoba (9). Colonoscopy-related quality measures have been identified to establish standards in the performance of colonoscopies; among these is the adenoma detection (AD) rate (ADR). Identifying factors that prognosticate $\mathrm{AD}$ are being targeted with the aim of optimizing the Cases and $>50,310$ deaths in the United States in 2014 (1). In Canada, CRC is estimated to rank second in incidence in men and third in women (2). Recent trends demonstrate a declining incidence and mortality from CRC $(1,3,4)$, and screening is believed to play a major role in these declines owing to the broad practice of opportunistic screening colonoscopy $(1,3,4)$. Data from the Nurses' Health Study (5) and the Health Professionals Follow-up cohort (6) demonstrate that both colonoscopy and sigmoidoscopy are associated with a reduced incidence of distal CRC, with screening colonoscopy also being associated with a reduction in the incidence of proximal CRC.

\footnotetext{
${ }^{1}$ Division of Gastroenterology, The McGill University Health Centre, Montreal General Hospital, McGill University, Montreal, Quebec; ${ }^{2}$ Division of

Gastroenterology, King Khalid University Hospital, King Saud University, Riyadh, Saudi Arabia; ${ }^{3}$ Division of Clinical Epidemiology, The McGill

University Health Centre, Montreal General Hospital, McGill University, Montreal, Quebec

Correspondence: Dr Alan N Barkun, Montreal General Hospital, 1650 Cedar Avenue, \#D7-148, Montreal, Quebec H3G 1 A4.

Telephone 514-934-8233, fax 514-934-8375, e-mail alan.barkun@muhc.mcgill.ca

Received for publication February 2, 2015. Accepted February 27, 2015
} 
TABLE 1

Characteristics of the $\mathbf{4 3 0}$ patients included in the study

\begin{tabular}{lc}
\hline Characteristic & \\
\hline Male sex & 56.3 \\
Age, years, mean \pm SD & $63.4 \pm 10.9$ \\
Previous colonoscopy & 27.7 \\
Previous polyp removal & 26.8 \\
Average-risk screening indication & 45.5 \\
Family history of colorectal cancer & 29.2 \\
Hereditary nonpolyposis colorectal cancer & 1.4 \\
Familial adenomatous polyposis & 1.9 \\
\hline
\end{tabular}

Data presented as \% unless otherwise indicated

effectiveness of colonoscopy. Some studies suggest that operator fatigue, either as a function of the time of day (10), queue position $(11,12)$ or performing emergency procedures the night before the colonoscopy (13), may affect quality (14) and the detection of polyps (15) and adenomas (16), while others have not found this association $(17,18)$. These metrics, as well as others, have been stressed in the clinical practice guideline by Tinmouth et al (19) for colonoscopy quality assurance in Ontario.

Accordingly, we sought to identify factors that affect AD during screening colonoscopy. More specifically, we examined the relationship between $\mathrm{AD}$ and the numbers of endoscopy hours and procedures performed before the index colonoscopy. We hypothesized that the numbers of hours worked and procedures performed, as well as the type of procedure mix, may influence AD.

\section{METHODS}

Patient and operator populations

The study cohort was identified using an endoscopic reporting database of individuals seen at a major tertiary care hospital in Montreal, Quebec. Both surgeons and gastroenterologists staff the endoscopy service. On average, 12,000 colonoscopies and gastroscopies are performed annually, of which since $2008,65 \%$ to $75 \%$ are colonoscopies. The study population included consecutive individuals who underwent a CRC screening colonoscopy (average and high risk, initial and follow-up) as indicated in the endoscopy report between June 1 and August 25, 2009. Individuals who underwent flexible sigmoidoscopy or for whom the colonoscopy indication was documented on the endoscopy report as other than CRC screening were excluded.

\section{Data collection}

Three trained research assistants abstracted data from electronic colonoscopic reports (Endoworks, Olympus Corporation, USA) of procedures performed during the study period, as well as from the corresponding electronic hospital pathology reports. All data were entered into standardized electronic case report forms.

Endoscopy sessions extended from morning (08:00) until late afternoon (16:00) and were staffed by the same endoscopists with no set ratio of colonoscopies to other endoscopic procedures. Endoscopies were performed by 12 attending staff ( 10 gastroenterologists, two colorectal surgeons) and the endoscopy lists did not include acute or hospitalized patients.

Collected information included demographic (age, sex) and clinical data (family history of CRC, previous colonoscopy, previous polypectomy and estimated CRC risk according to the endoscopist clinical assessment), and colonoscopic findings (quality of the bowel preparation, cecal intubation, photodocumentation of the cecum, the number of polyps detected and polyp location). For incomplete colonoscopies, the reason and level of the colon reached were recorded. The scoping activity of the endoscopist on the index day up to the point of the index colonoscopy was analyzed including the time devoted to performing any procedure (gastroscopy, colonoscopy or endoscopic ultrasound) and their numbers. Colonoscopies that were performed between 08:00 and
TABLE 2

Characteristics and findings of screening colonoscopies

\begin{tabular}{lc} 
Variable & $\begin{array}{c}\text { Percentage (95\% Cl) } \\
\text { or mean } \pm \text { SD }\end{array}$ \\
\hline Complete colonoscopy* & $96.3(94.0-97.9)$ \\
Cecal intubation & $95.7(93.4-97.7)$ \\
Photodocumentation of the cecum & $72.1(67.8-76.4)$ \\
Bowel preparation quality & \\
Good & $86.3(83.0-89.5)$ \\
Fair & $9.1(6.3-11.8)$ \\
Poor & $3.7(1.9-5.5)$ \\
Not documented & $0.9(0.02-1.8)$ \\
Polyp detected on index colonoscopy & $40.9(36.2-45.6)$ \\
Number of polyps & $0.8 \pm 1.7$ \\
Adenoma detected on current colonoscopy & $25.7(21.4-29.9)$ \\
Cancer & $0.07(0.0-2.0)$ \\
Advanced adenoma (from total adenomas) & $28.9(21.5-36.2)$ \\
Colonoscopies performed in the morning & $70.9(66.6-75.2)$ \\
Colonoscopies performed in the afternoon & $28.8(24.5-33.1)$ \\
Timing of colonoscopy not documented & $0.2(0.0-0.7)$ \\
\hline${ }^{*}$ Discrepancy between the cecal intubation rate and the colonoscopy com- \\
pletion rate may be related to incomplete documentation
\end{tabular}

12:00 were considered to be morning, and those performed between 12:01 and 16:00 were considered to be afternoon procedures.

$\mathrm{AD}$ was defined as a colonoscopy in which at least one adenoma was identified and determined based on a review of electronically filed pathology reports. The Institutional Review Board at the McGill University Health Centre (Montreal, Quebec) approved the study.

\section{Statistical analysis}

Sample size calculation was based on an a priori baseline adenoma prevalence in the centre's population of $30 \%$. Using the rule of 10 outcome events per predictor variable (20), and the authors' desire to include up to 12 variables in the multivariable model, it was estimated that 400 screening colonoscopies would be needed to provide sufficient accuracy.

Data analysis included descriptive statistics computed for continuous variables including means and SDs, and minimum and maximum values. Percentages were used for categorical variables. A hierarchical logistic regression model was used to examine the association between independent variables and AD. A two-level data structure was used for patient- and endoscopist-level clustering. Patient age and sex, and estimated CRC risk were adjusted according to the endoscopist's clinical assessment, previous colonoscopy, previous polypectomy, family history of CRC and bowel preparation quality.

An estimate of ADR variability within endoscopist speciality (gastroenterologist or surgeons) were computed from random intercepts for endoscopists and the specialty (surgeon or gastroenterologist) at the endoscopist level.

An exploratory univariable analysis was also performed to determine the optimal time threshold in hours for $\mathrm{AD}$, using ROC curve analysis; $\mathrm{P} \leq 0.05$ was considered to be statistically significant. All analyses were performed using SAS version 9.2 (SAS Institute, USA).

\section{RESULTS}

The authors identified 430 consecutive eligible patients who underwent a colonoscopy for a screening indication (June 1 to August 25, 2009). The characteristics of the 430 patients are summarized in Table 1 . The mean $( \pm$ SD) age was $63.4 \pm 10.9$ years and $56.3 \%$ were male. The bowel preparation quality was rated to be good in $86.3 \%$ of procedures and cecal intubation was achieved in $95.7 \%$ (Table 2). In total, the ADR was $25.7 \%$ (95\% CI $21.4 \%$ to $29.9 \%$ ) in the study population. The mean time from the beginning of the endoscopy session to the time 
TABLE 3

Results of between-group comparisons for detection of at least one adenoma on screening colonoscopy

\begin{tabular}{lcc}
\hline \multirow{2}{*}{ Variable } & \multicolumn{2}{c}{ Adenoma } \\
\cline { 2 - 3 } Male sex & $67.0(57.9-76.1)$ & $51.5(45.8-57.1)$ \\
Age, years, mean \pm SD & $67.0 \pm 11.3$ & $62.2 \pm 10.5$ \\
History of colonoscopy & $26.9(16.9-37.0)$ & $28.7(22.3-35.1)$ \\
Average-risk screening indication & $34.0(24.4-43.6)$ & $49.1(43.3-55.0)$ \\
Family history of colorectal cancer & $29.6(17.1-42.2)$ & $29.8(22.9-36.8)$ \\
Incomplete colonoscopy & $2.2(0.0-6.6)$ & $1.9(0.0-4.7)$ \\
Previous polyp removed & $43.5(28.6-58.4)$ & $21.8(15.2-28.4)$ \\
Cecum intubated & $97.2(94.0-1.00)$ & $95.1(92.6-97.5)$ \\
Good & $92.5(87.3-97.6)$ & $85.3(81.4-89.3)$ \\
Fair & $4.7(0.6-8.8)$ & $9.5(6.2-12.7)$ \\
Poor & $1.9(0.0-4.5)$ & $4.2(2.0-6.5)$ \\
Photodocumentation of the cecum & $82.1(74.7-89.5)$ & $68.7(63.5-73.4)$ \\
Polyp number, mean \pm SD & $2.2 \pm 2.0$ & $0.3 \pm 1.3$ \\
Hours to colonoscopy, mean \pm SD & $2.3 \pm 1.8$ & $2.9 \pm 2.2$ \\
Number of colonoscopies before & $3.1(2.5-3.7)$ & $4.0(3.6-4.4)$ \\
$\quad$ the index colonoscopy & & \\
Number of endoscopic procedures & $4.6(3.9-5.3)$ & $5.5(5.0-6.0)$ \\
$\quad$ before the index colonoscopy & & \\
Endoscopy in the morning & $77.4(69.3-85.5)$ & $68.7(63.5-73.4)$ \\
Male endoscopist & $85.9(79.1-92.6)$ & $91.9(88.8-94.9)$ \\
Surgical endoscopist specialty & $30.2(21.3-39.1)$ & $38.1(32.7-43.6)$ \\
\hline Da
\end{tabular}

Data presented as \% $(95 \% \mathrm{Cl})$ unless otherwise indicated. *Missing information for 17 patients

of the index colonoscopy was $163 \pm 125 \mathrm{~min}$, the number of endoscopic procedures (gastroscopies, colonoscopies or endoscopic ultrasounds) before the index colonoscopy was $5.3 \pm 4.0$ endoscopies and $3.7 \pm 3.5$ colonoscopies. The majority (70.9\%) of colonoscopies were performed in the morning.

Adenomas were detected more often in men $(67.0 \%$ versus $51.5 \%)$, and patients who were older (67.0 versus 62.2 years) had a history of polyp removal (43.5\% versus $21.8 \%$ ) and a higher number of polyps detected at the index colonoscopy ( 2.2 versus 0.3 ). The no adenoma group had a higher proportion of average-risk individuals (49.1\%) compared with the group with adenomas (34.0\%) (Table 3).

In univariable analysis, the significant predictors (at $\mathrm{P}=0.10$ level) included sex, age, average-risk indication, previous polyp removal, good bowel preparation, photodocumentation of the cecum, number of polyps detected, hours to colonoscopy, morning endoscopy and male endoscopist. On multivariable analysis, the only factor positively associated with AD was age (OR 1.06 [95\% CI 1.32 to 1.08$]$ ) per year. AD was lower in women (OR 0.44 [95\% CI 0.25 to 0.75$]$ ) and in patients with average-risk screening (OR 0.47 [95\% CI 0.27 to 0.80$]$ ). AD also decreased with an increase in the number of scoping hours elapsed until the index colonoscopy (OR 0.87 [95\% CI 0.76 to 0.99]) per hour.

A statistically significant difference was noted in the AD when comparing colonoscopies performed $\leq 3 \mathrm{~h}$ versus $>3 \mathrm{~h}$ after the start of the endoscopy session ( $\mathrm{P}=0.03$ ) (Figure 1$)$. No optimal cut-off could be identified using ROC curve analysis (area under the curve $=0.58$ ).

\section{DISCUSSION}

Multiple quality indicators have been proposed to optimize a common standard of practice with the aim of maximizing the detection of adenomas during screening colonoscopy and decreasing the incidence of CRC. Indeed, the ADR may be the most important quality indicator because it has been associated with interval CRC (21), and both CRC incidence and mortality (22).

The ADR in our study was comparable with that reported by other large groups of endoscopists (23-25). A variant definition of the ADR

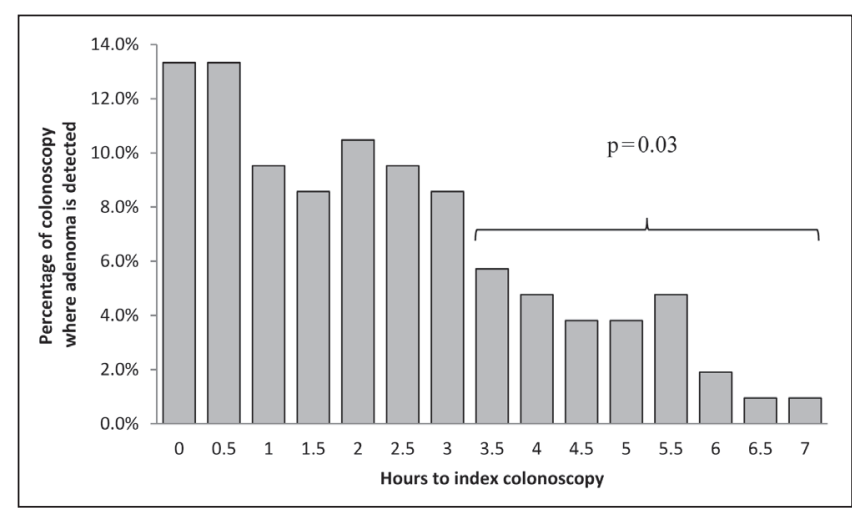

Figure 1) Percentage of colonoscopies in which adenomas were detected from the beginning of the endoscopy session $(h)$

is the proportion of adenomas detected per patient (26). Our definition of the ADR does not account for the presence of $>1$ adenoma per patient, which may be a shortcoming; nonetheless, we opted to use the traditional definition because of its broad adoption in the literature, which permits benchmarking with other studies $(27,28)$. There are limitations to the use of the ADR as a means for evaluating the performance of endoscopists because it may not be dependable (29) and it has been suggested that a large number of procedures (ie, 500 colonoscopies) may be required for it to be reliable (30).

Among patient characteristics, we observed that age predicted increased risk for adenoma(s) (OR 1.06 [95\% CI 1.32 to 1.08]); in contrast, AD was lower in women OR 0.44 (95\% CI 0.25 to 0.75 ). Both findings are consistent with previous studies (31-33). In univariable analysis, we also noted an association between $\mathrm{AD}$ and a history of polypectomy $(43.5 \%$ versus $21.8 \%)$.

There are numerous studies that have demonstrated that increased withdrawal time is associated with an increased ADR (23,34-36). We did not have withdrawal times for most endoscopists because time recording had not yet been implemented in a standardized way or widely disseminated as a quality measure during the study period in our institution. In a recent retrospective study, in which time recording was implemented, there was a statistically nonsignificant increase in polyps detected, and these were mostly small nonadenomatous polyps with no cancer potential $(36,37)$. Withdrawal times likely reflect a characteristic of the endoscopist and the degree of care and scrutiny that he/she takes in examining the colon. With overall improvement in colonoscopy quality and the adoption of other quality markers, withdrawal time may or may not remain an independent predictor and, thus, we do not believe that its absence invalidates the results of the present analysis, especially considering the high ADR in our study.

Importantly, we found that fewer adenomas were detected as the time to the index colonoscopy increased in multivariable analysis (OR 0.87 [95\% CI 0.76 to 0.99]), confirming our hypothesis. We showed a difference in $\mathrm{AD}$ when comparing colonoscopies performed $\leq 3 \mathrm{~h}$ versus $>3 \mathrm{~h}$ following the start of the endoscopy session using an exploratory univariable analysis; however, ROC curve analysis failed to reveal an optimal cut-off, perhaps because of inadequate statistical power. Possible explanations for the existence of such a threshold include operator fatigue and pressure for keeping the procedure scheduling on time. This finding was noted independently of bowel preparation and other aforementioned patient-related factors by using hierarchical logistic regression adjustment. Our results mirror some previous studies showing that the polyp detection rate decreased with time (16), although no threshold values have previously been proposed. Harewood et al (14) demonstrated that colonoscopy insertion times increased and cecal intubation rates decreased with successive procedures, supporting operator fatigue, although this study did not demonstrate a significant decline in lesion detection, which may be due to differences in staffing of morning and afternoon sessions (14), in 
which no endoscopist worked $>4 \mathrm{~h}$ and colonoscopies comprised only $33 \%$ of a given endoscopy list. Our study differs in that endoscopy sessions extended from morning until late afternoon staffed by the same endoscopist, with no set ratio in colonoscopies to other endoscopic procedures, possibly further favouring the detection of a threshold phenomenon. Lee et al (12) found that each elapsed hour in the day was associated with a $4.6 \%$ reduction in polyp detection as well as $5.4 \%$ reduction in polyp detection with each increase in the colonoscopy queue position (12); however, the authors attributed an inability to demonstrate a statistically significant decrease to the small number of procedures occupying a queue position $\geq 8$ (12). A decrease in polyp detection was not observed in studies in which endoscopy sessions were limited to $3 \mathrm{~h}(10)$ or half-day schedules $(17,18)$, further raising the notion of operator fatigue as noted by Spiegel (38). In a study by Kaneshiro et al (15), the effect of decreased AD as the day progressed persisted even after using visual reminders.

Recently, a study from the English Bowel Cancer Screening Programme (11) speculated endoscopist fatigue as a factor for decreased ADR because it was found that the earlier the colonoscopy in the procedural list, the higher the ADR. Operator fatigue has also been shown to affect $\mathrm{AD}$ during screening colonoscopy when performed by endoscopists who performed emergent on-call procedures the night before performing screening colonoscopies when compared with those who were not on call (30\% versus 39\%, respectively; $\mathrm{P}=0.043)(13)$.

Interestingly, operator fatigue has been noted in the surgical literature in which a randomized trial of frequent breaks for surgeons during their operations resulted in a reduction in the surgeon's serum cortisol levels and fewer intraoperative events when compared with the usual practice of no breaks (39). In the cardiology literature, adverse outcomes were noted in patients undergoing primary percutaneous coronary interventions during off hours (40), and were again observed in those undergoing nonurgent percutaneous coronary interventions later in the day when compared with those performed earlier (41). Fatigue has also been a focus of the aviation industry, in which there are established regulations to countermeasure its occurrence (42).

Other endoscopist characteristics have been examined in the literature. Neither sex nor endoscopist specialty were shown to affect AD in the present study (Table 3), a finding similar to that reported by Bannert et al (43), which included 52,506 screening colonoscopies performed by 196 endoscopists over a period of approximately 3.5 years. A recent population-based study from Alberta (44) found that primary care physicians performing colonoscopies achieved some of the quality benchmarks, including cecal intubation rates and ADRs, but included a mixture of patients who were symptomatic and others who were undergoing colonoscopies.

Adler et al (31) demonstrated an association between the number of continuing medical education meetings attended by the physician and ADR. This may be a reflection of the importance of endoscopist personality traits, and how this characteristic may affect individual performance parameters. Additional operator factors are also likely to play a role in ADR, such as the gazing pattern of the endoscopic image by the operator, as recently proposed (45).

Strengths of the present study include the elimination of the possibility of a Hawthorne effect due its the retrospective nature. We included all patients meeting eligibility criteria during the study period to reduce the potential for selection bias. Possible additional limitations include the lack of information regarding the date of the last colonoscopy and the CRC risk based on the endoscopists' assessment rather than an objective measure. Although both of these variables may induce a misclassification bias, the finding of a lower proportion of average-risk individuals with adenomas (34.0\% versus $49.1 \%$ ) is consistent with previous reports (46). Furthermore, in addition to a minor amount of missing data (reported in Table 3), additional information regarding some potential confounders were unavailable such as the presence of the metabolic syndrome (47-49), smoking (50-52), body mass index (53) and socioeconomic status (54), preventing more extensive patient-level adjustment for AD predictive factors. In addition, the present study was conducted at a single institution, which may limit generalizability, even though multiple endoscopy disciplines were represented.

\section{CONCLUSION}

Patient characteristics and increased time from start of the endoscopy session until the index colonoscopy were associated with $\mathrm{AD}$, with increased time to index colonoscopy negatively impacting AD. Operator fatigue may, thus, play a role, and has implications for optimal endoscopy session scheduling. Confirmatory studies are required to better characterize the effect of prolonged endoscopy sessions on the detection of adenomas during screening colonoscopy and identify an operational threshold.

ACKNOWLEDGEMENTS: The authors extend their sincere appreciation to the Deanship of Scientific Research at King Saud University for its funding of this research through the Research Group Project number RGPVPP-279.

DISCLOSURES: Majid Almadi, Maida Sewitch, Myriam Martel and Lawrence Joseph have no financial disclosures or conflicts of interest to declare. Dr Barkun is a consultant for Boston Scientific Inc, Olympus Canada Inc and Cook Inc. He has also received 'at arms-length' grant funding from both Boston Scientific Inc and Cook Inc.

\section{REFERENCES}

1. Siegel R, Ma J, Zou Z, Jemal A. Cancer statistics, 2014. CA Cancer J Clin 2014;64:9-29.

2. Canadian Cancer Society's Advisory Committee on Cancer Statistics. Canadian Cancer Statistics 2014. Toronto: OCCS.

3. Jemal A, Siegel R, Xu J, Ward E. Cancer statistics, 2010. CA Cancer J Clin 2010;60:277-300.

4. Edwards BK, Ward E, Kohler BA, et al. Annual report to the nation on the status of cancer, 1975-2006, featuring colorectal cancer trends and impact of interventions (risk factors, screening, and treatment) to reduce future rates. Cancer 2010;116:544-73.

5. Siegel R, Desantis C, Jemal A. Colorectal cancer statistics, 2014. CA Cancer J Clin 2014;64:104-17.

6. Nishihara R, Wu K, Lochhead P, et al. Long-term colorectal-cancer incidence and mortality after lower endoscopy. N Engl J Med 2013;369:1095-105.

7. Major D, Bryant H, Delaney M, et al. Colorectal cancer screening in Canada: Results from the first round of screening for five provincial programs. Current Oncol 2013;20:252-7.

8. Sewitch MJ, Jiang M, Fon Sing M, Barkun A, Joseph L. Screening polypectomy rates below quality benchmarks: A prospective study. World J Gastroenterol 2014;20:16300-5.

9. Singh H, Kaita L, Taylor G, Nugent Z, Bernstein C. Practice and documentation of performance of colonoscopy in a central Canadian health region. Can J Gastroenterol Hepatol 2014;28:185-90.

10. Munson GW, Harewood GC, Francis DL. Time of day variation in polyp detection rate for colonoscopies performed on a 3-hour shift schedule. Gastrointest Endosc 2011;73:467-75.

11. Lee TJ, Rees CJ, Blanks RG, et al. Colonoscopic factors associated with adenoma detection in a national colorectal cancer screening program. Endoscopy 2014;46:203-11.

12. Lee A, Iskander JM, Gupta N, et al. Queue position in the endoscopic schedule impacts effectiveness of colonoscopy. Am J Gastroenterol 2011;106:1457-65.

13. Benson M, Grimes I, Gopal D, et al. Influence of previous night call and sleep deprivation on screening colonoscopy quality. Am J Gastroenterol 2014;109:1133-7.

14. Harewood GC, Chrysostomou K, Himy N, Leong WL. Impact of operator fatigue on endoscopy performance: Implications for procedure scheduling. Dig Dis Sci 2009;54:1656-61.

15. Kaneshiro M, Ho A, Chan M, Cohen H, Spiegel BM. Colonoscopy yields fewer polyps as the day progresses despite using social influence theory to reverse the trend. Gastrointest Endosc 2010;72:1233-40. 
16. Chan MY, Cohen H, Spiegel BM. Fewer polyps detected by colonoscopy as the day progresses at a Veteran's Administration teaching hospital. Clin Gastroenterol Hepatol 2009;7:1217-23.

17. Freedman JS, Harari DY, Bamji ND, et al. The detection of premalignant colon polyps during colonoscopy is stable throughout the workday. Gastrointest Endosc 2011;73:1197-206.

18. Gurudu SR, Ratuapli SK, Leighton JA, Heigh RI, Crowell MD. Adenoma detection rate is not influenced by the timing of colonoscopy when performed in half-day blocks. Am J Gastroenterol 2011;106:1466-71.

19. Tinmouth J, Kennedy EB, Baron D, et al. Colonoscopy quality assurance in Ontario: Systematic review and clinical practice guideline. Can J Gastroenterol Hepatol 2014;28:251-74.

20. Vittinghoff E, McCulloch CE. Relaxing the rule of ten events per variable in logistic and Cox regression. Am J Epidemiol 2007;165:710-8.

21. Kaminski M, Regula J, Kraszewska E, et al. Quality indicators for colonoscopy and the risk of interval cancer. N Engl J Med 2010:1795-803

22. Corley DA, Jensen CD, Marks AR, et al. Adenoma detection rate and risk of colorectal cancer and death. N Engl J Med 2014;370:1298-306.

23. Barclay RL, Vicari JJ, Doughty AS, Johanson JF, Greenlaw RL. Colonoscopic withdrawal times and adenoma detection during screening colonoscopy. N Engl J Med 2006;355:2533-41.

24. Shaukat A, Oancea C, Bond JH, Church TR, Allen JI. Variation in detection of adenomas and polyps by colonoscopy and change over time with a performance improvement program. Clin Gastroenterol Hepatol 2009;7:1335-40.

25. Dellon ES, Lippmann QK, Sandler RS, Shaheen NJ. Gastrointestinal endoscopy nurse experience and polyp detection during screening colonoscopy. Clin Gastroenterol Hepatol 2008;6:1342-7.

26. Church J. Adenoma detection rate and the quality of colonoscopy: The sword has two edges. Dis Colon Rectum 2008;51:520-3.

27. Sanaka MR, Deepinder F, Thota PN, Lopez R, Burke CA. Adenomas are detected more often in morning than in afternoon colonoscopy. Am J Gastroenterol 2009;104:1659-64.

28. Peters SL, Hasan AG, Jacobson NB, Austin GL. Level of fellowship training increases adenoma detection rates. Clin Gastroenterol Hepatol 2010;8:439-42.

29. Saini SD, Schoenfeld P, Vijan S. Can the adenoma detection rate reliably identify low-performing endoscopists? Results of a modeling study. Dig Dis Sci 2013;58:1856-62.

30. Do A, Weinberg J, Kakkar A, Jacobson BC. Reliability of adenoma detection rate is based on procedural volume. Gastrointest Endosc 2013;77:376-80.

31. Adler A, Wegscheider K, Lieberman D, et al. Factors determining the quality of screening colonoscopy: A prospective study on adenoma detection rates, from 12,134 examinations (Berlin colonoscopy project 3, BECOP-3). Gut 2013;62:236-41.

32. Qumseya BJ, Coe S, Wallace MB. The effect of polyp location and patient gender on the presence of dysplasia in colonic polyps. Clin Transl Gastroenterol 2012;3:e20.

33. Corley DA, Jensen CD, Marks AR, et al. Variation of adenoma prevalence by age, sex, race, and colon location in a large population: Implications for screening and quality programs. Clin Gastroenterol Hepatol 2013;11:172-80.

34. Gellad ZF, Weiss DG, Ahnen DJ, Lieberman DA, Jackson GL, Provenzale D. Colonoscopy withdrawal time and risk of neoplasia at 5 years: Results from VA Cooperative Studies Program 380. Am J Gastroenterol 2010;105:1746-52.

35. Simmons DT, Harewood GC, Baron TH, et al. Impact of endoscopist withdrawal speed on polyp yield: Implications for optimal colonoscopy withdrawal time. Aliment Pharmacol Ther 2006;24:965-71.
36. Lee TJ, Blanks RG, Rees CJ, et al. Longer mean colonoscopy withdrawal time is associated with increased adenoma detection: Evidence from the Bowel Cancer Screening Programme in England. Endoscopy 2013;45:20-6.

37. Taber A RJ. Effect of simply recording colonoscopy withdrawal time on polyp and adenoma detection rates. Gastrointest Endosc 2010;71:782-6.

38. Spiegel BM. Does time of day affect polyp detection rates from colonoscopy? Gastrointest Endosc 2011;73:476-9.

39. Engelmann C, Schneider M, Kirschbaum C, et al. Effects of intraoperative breaks on mental and somatic operator fatigue: A randomized clinical trial. Surg Endosc 2011;25:1245-50.

40. Glaser R, Naidu SS, Selzer F, et al. Factors associated with poorer prognosis for patients undergoing primary percutaneous coronary intervention during off-hours: Biology or systems failure? JACC Cardiovascular interventions 2008;1:681-8.

41. Cantor WJ, Strauss BH, Graham MM, et al. Time of day and outcomes of nonurgent percutaneous coronary intervention performed during working hours. Am Heart J 2010;159:1133-8.

42. Caldwell JA, Mallis MM, Caldwell JL, et al. Fatigue countermeasures in aviation. Aviation, space, and environmental medicine 2009;80:29-59.

43. Bannert C, Reinhart K, Dunkler D, et al. Sedation in screening colonoscopy: Impact on quality indicators and complications. Am J Gastroenterol 2012;107:1837-48.

44. Kolber MR, Wong CK, Fedorak RN, Rowe BH. Prospective study of the quality of colonoscopies performed by primary care physicians: The Alberta Primary Care Endoscopy (APC-Endo) Study. PLoS One 2013;8:e67017.

45. Almansa C, Shahid MW, Heckman MG, Preissler S, Wallace MB. Association between visual gaze patterns and adenoma detection rate during colonoscopy: A preliminary investigation. Am J Gastroenterol 2011;106:1070-4.

46. Barret M, Boustiere C, Canard JM, et al. Factors associated with adenoma detection rate and diagnosis of polyps and colorectal cancer during colonoscopy in France: Results of a prospective, nationwide survey. PLoS One 2013;8:e68947.

47. Sato Y, Nozaki R, Yamada K, Takano M, Haruma K. Relation between obesity and adenomatous polyps of the large bowel. Dig Endosc 2009;21:154-7.

48. Siddiqui A, Pena Sahdala HN, Nazario HE, et al. Obesity is associated with an increased prevalence of advanced adenomatous colon polyps in a male veteran population. Dig Dis Sci 2009;54:1560-4.

49. Kaaks R, Toniolo P, Akhmedkhanov A, et al. Serum C-peptide, insulin-like growth factor (IGF)-I, IGF-binding proteins, and colorectal cancer risk in women. J Natl Cancer Inst 2000;92:1592-600.

50. Botteri E, Iodice S, Raimondi S, Maisonneuve P, Lowenfels AB. Cigarette smoking and adenomatous polyps: A meta-analysis. Gastroenterology 2008;134:388-95.

51. Giovannucci E, Colditz GA, Stampfer MJ, et al. A prospective study of cigarette smoking and risk of colorectal adenoma and colorectal cancer in U.S. women. J Natl Cancer Inst 1994;86:192-9.

52. Giovannucci E, Rimm EB, Stampfer MJ, et al. A prospective study of cigarette smoking and risk of colorectal adenoma and colorectal cancer in U.S. men. J Natl Cancer Inst 1994;86:183-91.

53. Hassan C, Pickhardt PJ, Marmo R, Choi JR. Impact of lifestyle factors on colorectal polyp detection in the screening setting. Dis Colon Rectum 2010;53:1328-33.

54. Singh SM, Paszat LF, Li C, He J, Vinden C, Rabeneck L. Association of socioeconomic status and receipt of colorectal cancer investigations: A population-based retrospective cohort study. CMAJ 2004;171:461-5. 


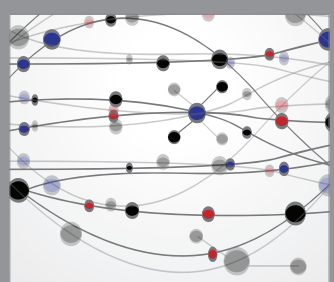

The Scientific World Journal
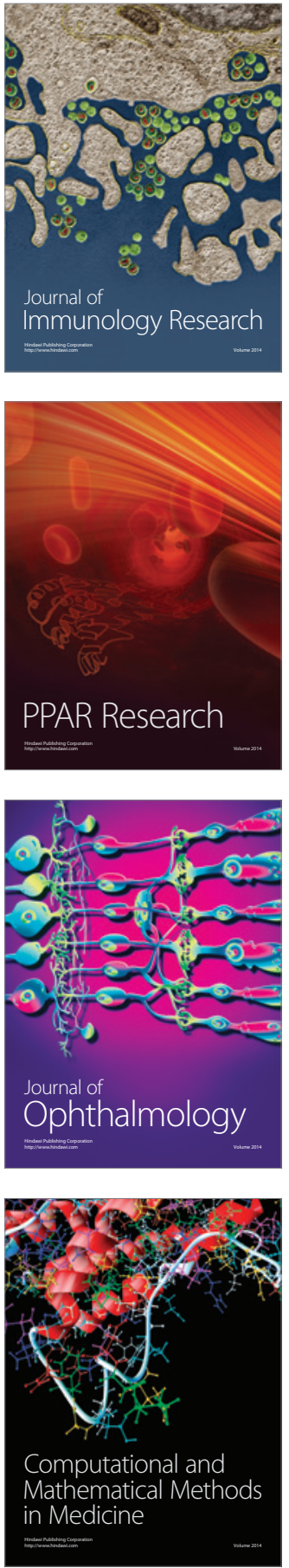

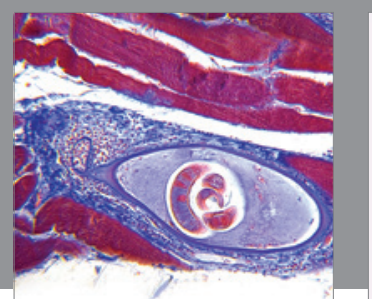

Gastroenterology Research and Practice

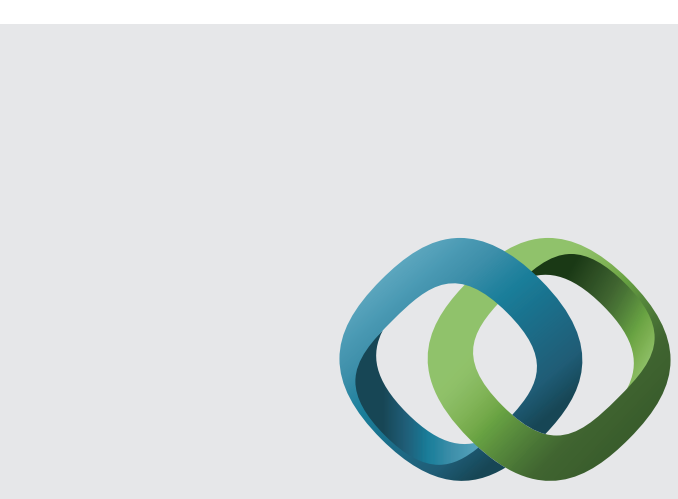

\section{Hindawi}

Submit your manuscripts at

http://www.hindawi.com
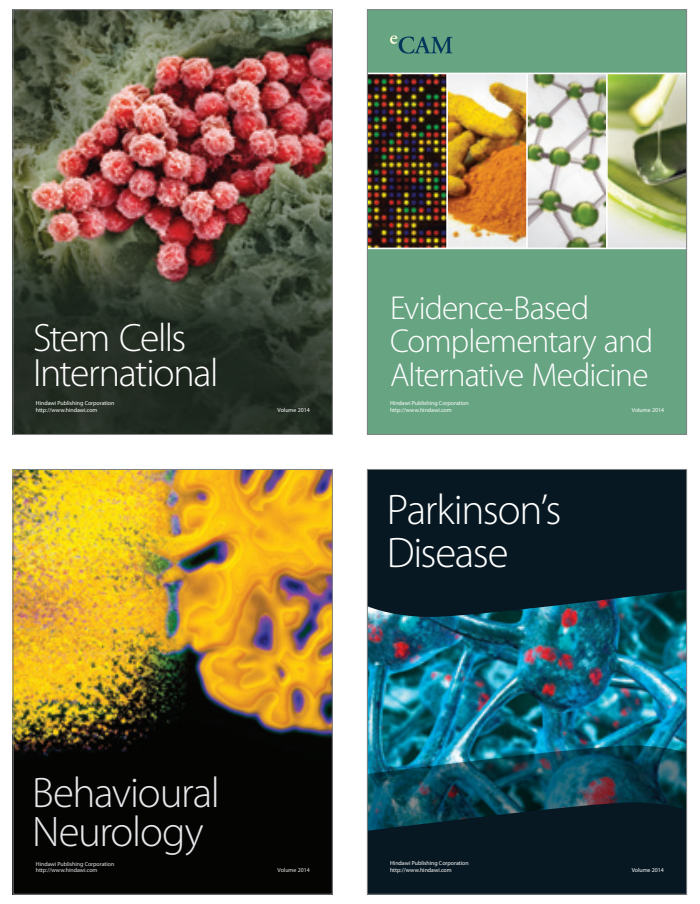
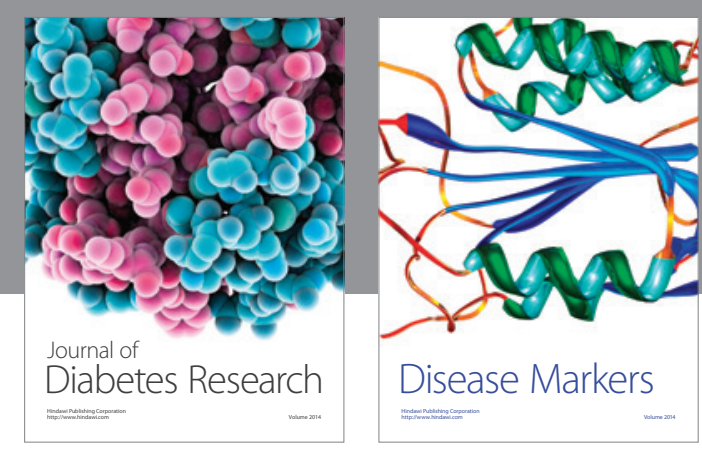

Disease Markers
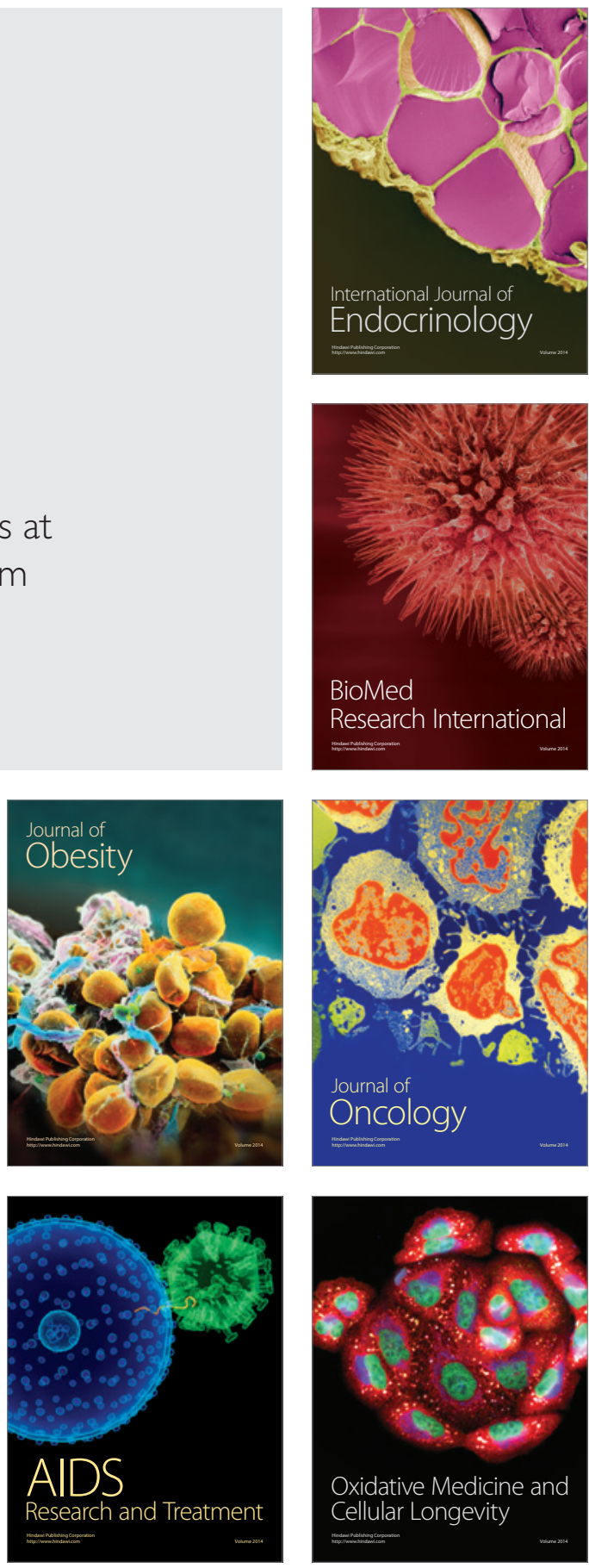